\title{
Back-Arc Basin Rocks in the Kohistan Arc Terrane, Northwestern Himalaya, Pakistan
}

\author{
Tahseenullah Khan†*, Mamoru Muratał, and Hiraoki Ozawał \\ † Geoscience Laboratory, Geological Survey of Pakistan, Shahzad Town, Islamabad, PAKISTAN \\ $\ddagger$ Department of Geosciences, Faculty of Science, Naruto University of Education, Tokushima, JAPAN \\ *To whom correspondence should be addressed.E-mail: bangash1444@hotmail.com
}

The Majne area lies west of Gilgit in Kar Gah valley that represents the middle part of the Kohistan arc terrane. This arc is accreted to the Karakoram continental plate along the Shyok suture and subsequently obducted onto the Indian continental plate along the Indus suture. The arc contains volcanic, plutonic and sedimentary rocks, which are variably deformed and metamorphosed. The main rock units of the arc include the Kamila amphibolites, the Chilas mafic-ultramafic complex and the Jaglot, Chalt and Yasin groups. The Kohistan batholith intrudes all rock formations except Kamila amphibolites.

Our main interest is in the Jaglot group, which occupies the east central part of the arc terrane and includes from bottom to top, (i) the Gilgit formation, (ii) the Gashu-confluence volcanics, and (iii) the Thelichi formation.

Based on field observation and petrological study, we reevaluate stratigraphy of the Thelichi formation and report for the first time doleritic and basaltic dykes and gabbros. The NWSE trending dykes unit is about $100-500 \mathrm{~m}$ wide and $15 \mathrm{~km}$ long and composed entirely of dykes. The width of these dykes is not constant and ranges from about $10 \mathrm{~cm}$ to $5 \mathrm{~m}$. In the dykes unit, the doleritic dykes are split and intruded by younger basaltic dykes. A $2 \mathrm{~m}$ wide volcanic breccia zone is present in the upper part of the dykes unit, which is overlain by the Thelichi formation comprising bedded chert, phyllite, greenschist volcaniclastics, meta-greywacke, marble (meta-micritic limestone), conglomerates and the turbidites (pebbly slate, silty and sandy quartzite). The meta-sedimentary rocks of the Thelichi formation are frequently intruded by the doleritic, basaltic, and dacitic to rhyolitic dykes (minor).

The gabbroic unit is about 50-100 m wide. Its northwest and southeast extension has not been marked due to rugged topography and inaccessibility. The gabbro at the base is characterized by layered structure transitional into the overlying isotropic gabbro. The gabbro contains diopsidic-augite and plagioclase as primary minerals. The dykes unit and the individual dykes intruding the Thelichi formation comprise mainly hornblende (altered from augite), augite (relics and grains; ophitic to sub-ophitic), titaniferous augite (relics), chlorite, epidote, sphene, ilmenite and titanomagnetite.

Geochemical studies show that the dykes are basaltic in composition and characterized by high $\mathrm{TiO}_{2}, \mathrm{Na}_{2} \mathrm{O}$ and $\mathrm{Fe}_{2} \mathrm{O}_{3}$ and low $\mathrm{K}_{2} \mathrm{O}$. They show wide range in $\mathrm{MgO}$ in spite of restricted $\mathrm{SiO}_{2}$ contents. High $\mathrm{TiO}_{2}, \mathrm{Na}_{2} \mathrm{O}$ and $\mathrm{Fe}_{2} \mathrm{O}_{3}$, and low $\mathrm{K}_{2} \mathrm{O}$ characterize the gabbros also. The n-MORB-normalized plot shows slight depletion in HFSE for the comparatively less fractionated dykes

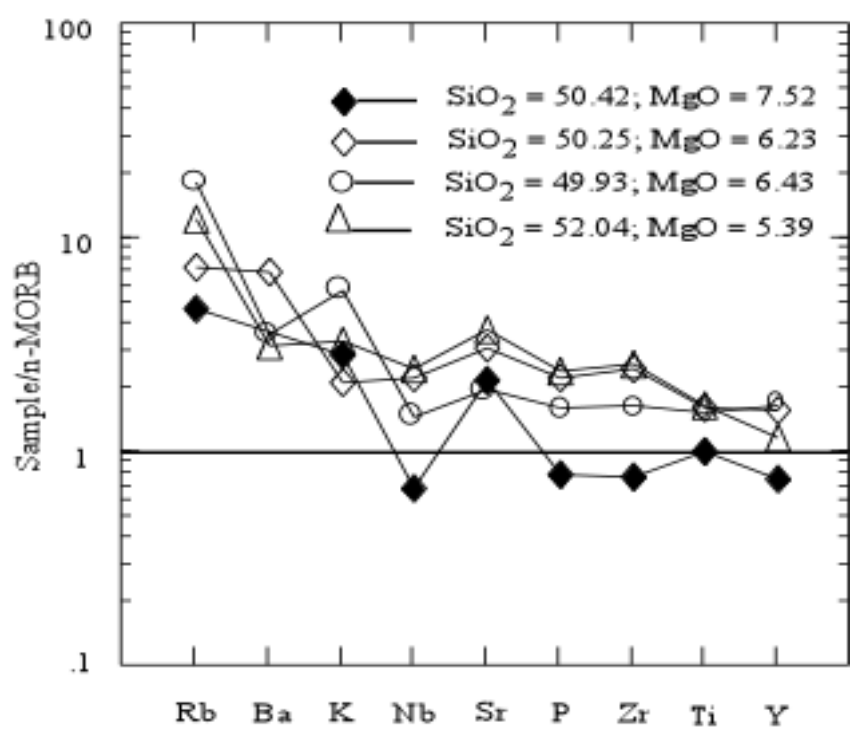

FIGURE 1. The n-MORB-normalized pattern for dykes of Majne area, Kohistan arc terrane, North Pakistan

with negative $\mathrm{Nb}$ anomaly in sample with $\mathrm{SiO} 2=50.42$ wt. $\%$ and $\mathrm{MgO}=7.52$ wt.\% (Figure 1). The rest of the dykes show enrichment in both the LIL and the HFS elements. The $\mathrm{Zr} / \mathrm{Nb}$ ratio of all the dykes falls in the range of 33-36 exhibiting n-MORB characteristics.

The enrichment in minor, trace and rare-earth elements and the linear trends of major and trace elements in entire dykes unit suggest that they are genetically coherent to a common MORB magma source possibly by high degree $20-30 \%$ of partial melting for the initial melt, followed possibly by low degree of partial melting and/or accompanied by fractional crystallization at low pressure. The evolved and/or fractionated dykes may also demonstrate geochemistry of crust contaminated MORB(?). The initial MORB source melt seems to have subduction component as depicted by negative $\mathrm{Nb}$ anomaly in one of the dyke sample. It is to be noted that MORB- and island-arc types geochemical features are characteristic of back-arc basin basalts. We, therefore, conclude that the Majne rocks represent ocean floor of back-arc or marginal basin, formed due to extension. 